\title{
Effect of feeding varying levels of groundnut haulms on feed intake and growth performance in broiler chickens
}

\author{
N. K. Ribadiya ${ }^{1}$, H. H. Savsani ${ }^{1}$, S. S. Patil ${ }^{1}$, D. D. Garg${ }^{2}$, M. R. Gadariya ${ }^{3}$, V. K. Karangiya ${ }^{1}$ and A. P. Gajera ${ }^{3}$
}

1. Department of Animal Nutrition, College of Veterinary Science and A. H., Junagadh Agricultural University, Junagadh, India; 2. Department of Animal Nutrition, Intensive Livestock Farm Complex, College of Veterinary Science and A. $\mathrm{H}$., Junagadh Agricultural University, Junagadh, India; 3. Department of Animal Nutrition, Cattle Breeding Farm, Junagadh Agricultural University, Junagadh, India.

Corresponding author: N. K. Ribadiya, e-mail: nilayribadiya@gmail.com, HHS: hhsavsani@jau.in, SSP: drsspatt@gmail.com,DDG: drddgarg@gmail.com, MRG: mr_gadariya@jau.in, VKK: vijay.vet007@gmail.com, APG: apgajera@yahoo.in

Received: 18-10-2014, Revised: 22-12-2014, Accepted: 26-12-2014, Published online: 09-02-2015

doi: 10.14202/vetworld.2015.139-142. How to cite this article: Ribadiya NK, Savsani HH, Patil SS, Garg DD, Gadariya MR, Karangiya VK, Gajera AP (2015) Effect of feeding varying levels of groundnut haulms on feed intake and growth performance in broiler chickens, Veterinary World, 8(2): 139-142.

\begin{abstract}
Aim: This study was carried out to evaluate groundnut haulms (GNH) as alternate feed source by its incorporation and assessment in terms of feed intake and growth performance in the diets of broilers.

Materials and Methods: A total of 240 1-day-old Cobb-400 broiler chicks were randomly assigned to four dietary treatments each with three replicates $(\mathrm{n}=60)$. Experimental Birds in group T1 were fed with conventional feed while birds in T2, T3, T4 were fed containing $2 \%, 4 \%$, and $6 \%$ of GNH replacing maize and soyabean on iso-nitrogenous basis.
\end{abstract}

Results: Feed intake increases significantly $(\mathrm{p}>0.05)$ with increasing level of GNH in the diets of experimental birds. Highest feed intake was recorded in T4 (6\% GNH), followed by T3 (4\% GNH) than T2 (2\% GNH) and T1 (control). Birds fed GNH gained significantly $(\mathrm{p}<0.05)$ higher body weight than birds fed the control diet. Birds in T4 [6\% GNH] gained highest body weight, followed by T3 $(4 \% \mathrm{GNH})$ than T2 $(2 \% \mathrm{GNH})$ and T1 (control). However, feed conversion ratio (FCR) remained non-significant for all treatment groups.

Conclusion: On the basis of the results of this study, it is concluded that supplementation of GNH can successfully replace costly ingredients like maize and soybean meal in the diets of broiler birds up to the level of 6 percent of concentrate mixture without any harmful effects on feed intake, growth and FCR.

Keywords: body weight, broiler chickens, feed intake, groundnut haulms

\section{Introduction}

Over a period due to the combined efforts of government, private players, and farmers, the poultry industry has become a full-fledged organized sector and now stands as one of the fastest growing industries in India. Poultry occupies an important place in Indian economy by contributing more than Rs. 11,000 crores to the national Gross Domestic Product. It also ranks $3^{\text {rd }}$ and $5^{\text {th }}$ with respect to production of egg and meat in the world [1]. However, a major constraint to poultry production in India is the very high cost of conventional feeding stuff and therefore cost of poultry production has gone up substantially in recent years [2]. Since feed cost is a major expense in poultry production, accounting for $60-70 \%$ of total production cost [3], search for cheap, locally available and equally nutritive feed source to partially substitute commercial poultry diet is ever increasing $[4,5]$.

Leaf meal is one of the alternative feed, which has been incorporated in the diets of poultry as a means of reducing the high cost of conventional protein sources [6]. There is evidence in the literature of

Copyright: The authors. This article is an open access article licensed under the terms of the Creative Commons Attributin License (http:// creative commons.org/licenses/by/2.0) which permits unrestricted use, distribution and reproduction in any medium, provided the work is properly cited. the beneficial effects of using leaf meal from different sources in poultry production [7-9]. Ground nut (Arachis hypogaea) haulms (GNH) are the residue left after harvesting groundnut and are produced at very high quantity in Saurashtra, which can be used in a similar way to different leaf meals in the diet of poultry. It is a good source of protein and calcium [10] and is referred in vernaculars language as guitar. GNH have good nutritive value and contains about contain $12.4 \%$ crude protein $(\mathrm{CP})$ on dry matter (DM) basis [11]. Although abundant research has been carried out on feeding GNH in ruminants very few information is available on feeding GNH in poultry.

Hence, the present study has been carried out to assess the effect of feeding varying levels of GNH on feed intake and growth performance in broiler birds.

\section{Materials and Methods}

The experiment was carried out at the Shambhu poultry farm at Dhoraji, Dist. Rajkot, Gujarat, India.

\section{Ethical approval}

This research was carried out after approval of Institutional Animal Ethics Committee.

\section{Source and processing of GNH}

GNH used in this study was bought from Cattle Breeding Farm, Junagadh Agricultural University, Junagadh. 


\section{Experimental birds and diets}

Day old 240 broiler chicks of cobb-400 strain with average body weight 45.17-46.47 g were wing banded and distributed randomly into four groups having three replicates of 20 birds each by randomized block design and allocated to four dietary treatments as T1, T2, T3 and T4 using to the four experimental diets. Experimental Birds in group T1 were fed with conventional concentrate mixture while birds in $\mathrm{T} 2$, T3, T4 groups were fed with concentrate mixture containing $2 \%, 4 \%$ and $6 \%$ of GNH replacing maize soyabean on iso-nitrogenous basis. Ingredient and chemical compositions of these starter and finisher rations are presented in Table- 1 and- 2 respectively. Chemical composition of GNH is given in Table-3.

\section{Feeding and management procedures}

All the experimental birds were housed in a well-ventilated shed in deep litter pens under uniform managerial conditions. The reference and test concentrate mixtures and clean drinking water was supplied to the birds ad libitum throughout the study period to meet the nutrient as per [12]. The body weights of all the birds were recorded weekly in the morning, before feeding and watering. The amount of feed offered and residue left after $24 \mathrm{~h}$ was measured to find out feed intake of feed. Feed conversion ratio (FCR) was calculated by dividing the feed intake by weight gain. Vaccination and other routine poultry management practices were carried out neatly.

Table-1: Ingredient and chemical composition of starter feeds.

\begin{tabular}{|c|c|c|c|c|}
\hline & T1 & T2 & T3 & T4 \\
\hline \multicolumn{5}{|l|}{ Feed ingredient $(\mathrm{kg})$} \\
\hline Maize & 59 & 58 & 56 & 54 \\
\hline Soyabean & 36 & 35 & 35 & 35 \\
\hline GNH & 0 & 2 & 4 & 6 \\
\hline Fat/oil & 2 & 2 & 2.3 & 2.7 \\
\hline Lime stone & 0.8 & 0.8 & 0.8 & 0.8 \\
\hline Di calcium phosphate & 1.7 & 1.7 & 1.7 & 1.7 \\
\hline Salt & 0.35 & 0.35 & 0.35 & 0.35 \\
\hline Methionine & 0.11 & 0.11 & 0.11 & 0.11 \\
\hline Lysine & 0.15 & 0.15 & 0.15 & 0.15 \\
\hline Trace minerals & 0.0625 & 0.0625 & 0.062 .5 & 0.0625 \\
\hline Vitamin premix & 0.050 & 0.050 & 0.050 & 0.050 \\
\hline Toxin binder & 0.1 & 0.1 & 0.1 & 0.1 \\
\hline Total & 100.00 & 100.00 & 100.00 & 100.00 \\
\hline \multicolumn{5}{|l|}{$\begin{array}{l}\text { Chemical composition } \\
\text { (\% DM basis) }\end{array}$} \\
\hline ME (Kcal) & 3020.5 & 2999.0 & 2995.0 & 2966.5 \\
\hline DM & 95.52 & 95.99 & 95.99 & 95.99 \\
\hline OM & 90.4 & 90.32 & 89.98 & 89.58 \\
\hline $\mathrm{CP}$ & 21.96 & 21.90 & 21.83 & 21.77 \\
\hline $\mathrm{CF}$ & 3.65 & 4.10 & 4.45 & 5.16 \\
\hline $\mathrm{EE}$ & 3.33 & 3.80 & 3.92 & 4.00 \\
\hline NFE & 61.46 & 60.52 & 59.78 & 58.65 \\
\hline Total ash & 9.60 & 9.68 & 10.02 & 10.42 \\
\hline Silica & 0.85 & 1.52 & 1.64 & 1.76 \\
\hline Calcium & 1.02 & 1.01 & 1.00 & 0.99 \\
\hline Phosphorus & 0.45 & 0.45 & 0.46 & 0.47 \\
\hline
\end{tabular}

$\mathrm{ME}=$ Metabolic energy, $\mathrm{DM}=$ Dry matter, $\mathrm{OM}=$ Organic matter, $\mathrm{CP}=$ Crude protein, $\mathrm{CF}=$ Crude fiber, NFE $=$ Nitrogen free extract, $\mathrm{GNH}=$ Groundnut haulms, EE=Ether extract

\section{Chemical and statistical analysis}

Samples of feeds were milled to pass through a $1 \mathrm{~mm}$ sieve and then analyzed following the methods of AOAC (1995) to determine DM by the oven drying method (934.01), organic matter by muffle furnace incineration (967.05), CP by kjeldahl method (984.13) $(n \times 6.25)$, ether extract (EE; 920.39), ash (942.05). The data collected on various parameters were analyzed using the method [13].

\section{Results and Discussion}

Nutrient composition of GNH and experimental rations

Nutrient composition of $\mathrm{GNH}$ and different concentrate mixtures are given in Table-1. The GNH contains about $9.82 \% \mathrm{CP}$ and $34.05 \%$ nitrogen free extract, and its nutrient composition was comparable

Table-2: Ingredient and chemical composition of finisher feeds.

\begin{tabular}{|c|c|c|c|c|}
\hline & T1 & T2 & T3 & T4 \\
\hline \multicolumn{5}{|l|}{ Feed ingredient $(\mathrm{kg})$} \\
\hline Maize & 65 & 65 & 65 & 65 \\
\hline Soyabean & 30 & 28 & 26 & 24 \\
\hline GNH & 0 & 2 & 4 & 6 \\
\hline Fat/oil & 2 & 2 & 2 & 2 \\
\hline Lime stone & 0.8 & 0.8 & 0.8 & 0.8 \\
\hline Di calcium phosphate & 1.7 & 1.7 & 1.7 & 1.7 \\
\hline Salt & 0.35 & 0.35 & 0.35 & 0.35 \\
\hline Methionine & 0.11 & 0.11 & 0.11 & 0.11 \\
\hline Lysine & 0.18 & 0.18 & 0.18 & 0.18 \\
\hline Trace minerals & 0.0625 & 0.0625 & 0.062 .5 & 0.0625 \\
\hline Vitamin premix & 0.050 & 0.050 & 0.050 & 0.050 \\
\hline Toxin binder & 0.1 & 0.1 & 0.1 & 0.1 \\
\hline Total & 100.00 & 100.00 & 100.00 & 100.00 \\
\hline \multicolumn{5}{|l|}{$\begin{array}{l}\text { Chemical composition } \\
\text { (\% DM basis) }\end{array}$} \\
\hline ME (Kcal) & 3077.5 & 3069.5 & 3061.5 & 3053.5 \\
\hline DM & 95.54 & 95.98 & 95.99 & 95.99 \\
\hline OM & 90.38 & 90.32 & 89.90 & 88.76 \\
\hline $\mathrm{CP}$ & 19.89 & 19.35 & 18.92 & 18.56 \\
\hline CF & 3.44 & 3.87 & 4.43 & 5.01 \\
\hline $\mathrm{EE}$ & 3.35 & 3.77 & 3.82 & 4.02 \\
\hline NFE & 63.70 & 63.33 & 62.73 & 61.17 \\
\hline Total ash & 9.62 & 9.68 & 10.10 & 11.24 \\
\hline Silica & 0.84 & 1.45 & 1.58 & 1.70 \\
\hline Calcium & 0.96 & 0.97 & 0.99 & 1.00 \\
\hline Phosphorus & 0.43 & 0.45 & 0.45 & 0.44 \\
\hline
\end{tabular}

$\mathrm{ME}=$ Metabolic energy, $\mathrm{DM}=$ Dry matter, $\mathrm{OM}=$ Organic matter, $\mathrm{CP}=$ Crude protein, $\mathrm{CF}=$ Crude fiber, NFE $=$ Nitrogen free extract, $\mathrm{GNH}=$ Groundnut haulms, $\mathrm{EE}=$ Ether extract

Table-3: Chemical composition of GNH (In \% DM basis).

\begin{tabular}{lc}
\hline DM & 97.83 \\
OM & 74.64 \\
CP & 9.82 \\
CF & 27.80 \\
EE & 2.97 \\
NFE & 34.05 \\
Total ash & 25.36 \\
Calcium & 2.94 \\
Phosphorus & 0.31 \\
Silica & 13.14 \\
\hline
\end{tabular}

$\mathrm{DM}=$ Dry matter, $\mathrm{OM}=$ Organic matter, $\mathrm{CP}=$ Crude protein, $\mathrm{CF}=$ Crude fiber, NFE=Nitrogen free extract, $\mathrm{GNH}=$ Groundnut haulms, EE=Ether extract 
to values reported by earlier workers [6]. All the feeds were iso-nitrogenous and comparable with respect to their proximate composition.

\section{Feed intake ( $g /$ bird)}

The average total feed intake showed a significant difference $(p>0.05)$ among different dietary treatments (Table-4). Feed consumption of birds in different groups was increased significantly $(p>0.05)$ with increased inclusion level of GNH. The highest feed consumption was recorded in birds fed T4 diet, followed by T3, T2 and T1 group. Inclusion of higher levels GNH from 0 to 6 percent (from $\mathrm{T} 1$ to $\mathrm{T} 4$ groups) has also leads to linear increase in crude fiber content of different ration which might be along with lower dry matter digestibility are responsible for increase feed intake on higher level of supplementation of GNH in broilers [14]. Reported similar findings on feeding Moringa oleifera leaf meal (MOLF), Acacia angustissima and Moringa stenopetala leaf meal respectively in the diets of broilers $[6,15,16]$.

\section{Body weight gain (g) and FCR}

Total body weight gain (g) and weekly body weight gain $(\mathrm{g})$ for the period of 42 days were significantly $(\mathrm{p}<0.001)$ higher in GNH supplemented groups (T2, T3 and T4) than control (T1) group with increasing trend from T1-T4 groups (Table-4). While, FCR (kg DMI/kg gain) of the experimented birds showed non-significant difference among different groups. Improvement in body weight in treatment groups T4, T3 and T2 might be due to the better feed intake and nutrient availability as $\mathrm{GNH}$ is a good source of vital nutrients like EE and calcium [6] resulting in better performance. [16] conducted an experiment by using MOLF and found that increased body weight in treatment groups. Similarly [4] studied effect of sun dried neem leaf meal in Ross birds and found increased body weight in treatment groups.

Results showed that the treatment effect on live weight, dressed weight and dressing percent were significant $(p<0.05)$ increasing as increase in GNH percent in feed. All organs showed significant $(p<0.05)$ difference in their weights among treatment groups, but except heart, no one showed a definite pattern.

\section{Carcass quality}

Statistical analysis of the value indicates significant $(p<0.05)$ difference among different treatment groups in respect to live weight and dressed weight of birds. T4 group had the highest value and was significantly $(\mathrm{p}<0.05)$ higher than T2 group and T1 group while $\mathrm{T} 3$ and $\mathrm{T} 2$ group were significantly higher than $\mathrm{T} 1$ group. This was due to higher average body weight of treatment groups than the control group at the end of the experimental period. The results of statistical analysis revealed almost similar significant effect of GNH on dressing percentage as live weight. There was significant $(\mathrm{p}<0.05)$ difference between $\mathrm{T} 4$ group and T1 treatment group. While dressing percent of $\mathrm{T} 2$, T3 and T4 group was not significantly differ. This indicates that higher body weight gain of treatment groups resulting in higher dressing percent. Similar findings were reported by $[4,17]$.

While statistical analysis indicates non-significant $(p>0.05)$ difference among different treatment groups in respect to weights of different organs like gizzard, liver, intestine, shank except heart. Weight of heart among different treatment groups indicates that GNH have a positive effect on heart weight. This may be due higher body weight of birds in treatment groups resulting in more efficient work of the heart. Similar significant differences in heart weight were reported $[4,17]$ by investigating the effects of MOLF and cassava leaf meal, respectively.

\section{Conclusion}

At the end, on the basis of the performance of experimental birds in respect to feed intake, body weight, body weight gain, and FCR it seems to appear that incorporation of GNH at $6 \%$ level in the broilers ration, can successfully replace costly ingredients like maize and soybean meal in the diets of broiler birds without any harmful effects on feed intake, growth and FCR.

\section{Authors' Contribution}

HHS conceptualized the aim of this study, designed and supervised the experiment. NKR executed the experiments and conducted statistical analysis. SSP, DDG and MRG has drafted, corrected and revised the manuscript. APG and VKK have carried out laboratory analysis of feed samples. All authors read and approved the final manuscript.

Table-4: Performance of experimental birds.

\begin{tabular}{|c|c|c|c|c|c|}
\hline \multirow[t]{2}{*}{ Attributes } & \multicolumn{4}{|c|}{ Treatments } & \multirow[t]{2}{*}{ SEM } \\
\hline & T1 & T2 & T3 & T4 & \\
\hline \multicolumn{6}{|l|}{ Body weight $(\mathrm{kg})$} \\
\hline Initial & 45.80 & 45.17 & 46.47 & 45.58 & 0.30 \\
\hline Final & $1376.88^{d}$ & $1422.00^{c}$ & $1526.78^{b}$ & $1596.82^{\mathrm{a}}$ & 13.63 \\
\hline Average final body weight gain ( $\mathrm{g}$ ) & $1331.08^{d}$ & $1376.84^{c}$ & $1480.31^{b}$ & $1551.23^{\mathrm{a}}$ & 25.38 \\
\hline Average weekly weight gain $(\mathrm{g})$ & $210.35^{b}$ & $213.55^{\mathrm{b}}$ & $234.00^{a}$ & $245.23^{a}$ & 3.69 \\
\hline Average total feed intake & $2684.22^{d}$ & $2808.99^{c}$ & $3026.65^{b}$ & $3268.39^{a}$ & 40.37 \\
\hline Feed conversion ratio & 1.96 & 1.95 & 1.98 & 2.00 & 0.01 \\
\hline
\end{tabular}

Means with different superscript differ significantly $(p<0.05)$, SEM=Standard error of mean 


\section{Acknowledgments}

The authors acknowledge the facilities and financial support provided for the present study from Junagadh Agricultural University, Junagadh, Gujarat, India.

\section{Competing Interests} interests.

The authors declare that they have no competing

\section{References}

1. BAHS. (2012) Basic Animal Husbandry Statistics. Ministry of Agriculture, Govt. of India, New Delhi.

2. Onyimonyi, A.E., Adeyemi, O. and Okeke, G.C. (2009) Performance and economic characteristics of broilers fed varying dietary levels of neem leaf meal (Azadirachta indica). Int. J. Poult. Sci., 8(3): 256-259.

3. Chang, J. (2005) Malaysia Poultry and Products Annual, GAIN Report Number: MY5036. USDA Foreign Agricultural Service, Kuala Lumpur.

4. Onu, P.N. and Aniebo, A.O. (2011) Influence of Moringa Oleifera leaf meal on the performance and blood chemistry of starter broilers. Int. J. Food Agric. Vet. Sci., 1(1): 38-44.

5. Raghavan, V. (2009) Malaysia feed industry-issues and challenges. In: Proceedings of $3^{\text {rd }}$ International Conferences on Animal Nutrition (ICAN) 2008: Enhancing Feed Utilization Through Technology (MARDI). p3-14.

6. Murthy, K.S., Dutta, K.S., Tajane, K.R., Ravikala, K. and Gajbhiye, P.U. (2006) Groundnut haulms- Alternate roughage for lactating cows. Indian J. Anim. Nutr., 23(2): 110-112.

7. D'Mello, J.P.E., Acamovic, T. and Walker, A.G. (1987) Evaluation of Leucaena leaf meal for broiler growth and pigmentation. Trop. Agric. (Trinidad), 64: 33-35.

8. Egbenwade, O.O. and Olorede, B.R. (2003) Substitution of groundnut cake with mistletoe (Loranthus bengwensis) leaf meal in broiler meal. In: Proceeding of the $8^{\text {th }}$ Annual conference of the Animal Science Association of Nigeria (ASAN). p1-3.

9. Gadzirayi, C.T., Masamha, B., Mupangwa, J.F. and Washaya, S. (2012) Performance of broiler chickens fed on mature Moringa oleifera leaf meal as a protein supplement to soyabean meal. Int. J. Poult. Sci., 11(1): 5-10.

10. Preston, T.R. (1995) Tropical Animal Feeding: A Manual for Research Workers. Animal Production and Health Paper No. 126. FAO, Rome.

11. Melesse, A., Getye, Y., Berihun, K. and Banerjee, S. (2013) Effect of feeding graded levels of Moringa stenopetala leaf meal on growth performance, carcass traits and some serum biochemical parameters of Koekoek chickens. Livest. Sci., 157(2-3): 498-505. Available from: http://www.dx.doi. org/10.1016/j.livsci.

12. BIS. (1992) Indian Standards: Poultry Feed Specifications. $4^{\text {th }}$ Revision. Beauro of Indian Standards, New Delhi.

13. Snedecor, G.W. and Cochran, W.G. (1994) Statistical Methods. $8^{\text {th }}$ ed. Oxford and IBH Publishing Co., New Delhi.

14. Fasuyi, O.A., Dairo, F.A.S. and Adeniji, A.O. (2008) Tropical vegetable (Amaranthus cruentus) leaf meal as alternative protein supplement in broiler starter diets: Bio nutritional evaluation. J. Cent. Eur. Agric., 9(1): 23-34.

15. Khan, M.K.A., Akbar, M.A., Khaleduzzaman, A.B.M. and Rahman, M.M. (2009) Utilization of Leucaena and Sesbania leaf meals as protein supplements in broiler ration. Bangladesh J. Anim. Sci., 38(1\&2): 123-131.

16. Ocak, N., Erener, G., Burak, A.K., Sungu, M., Altop, A. and Ozmen, A. (2008) Performance of broilers fed diets supplemented with dry peppermint (Mentha piperita L.) or thyme (Thymus vulgaris L.) leaves as growth promoter source. Czech J. Anim. Sci., (4): 169-175.

17. Iheukwumere, F.C., Ndubuisi, E.C., Mazi, E.A. and Onyekwere, M.U. (2008) Performance, nutrient utilization and organ characteristics of broilers fed cassava leaf meal (Manihot esculenta, Crantz). Pak. J. Nutr., 7: 13-16. 